\title{
Molecular Cage Promoted Aerobic Oxidation or Photo-Induced Rearrangement of Spiroepoxy Naphthalenone
}

\author{
Peiming Cheng ${ }^{1,2}\left(\mathbb{D}\right.$, Lixuan Cai ${ }^{2}$, Danni Yan ${ }^{2}$, Lipeng Zhou ${ }^{2}\left(\mathbb{D}\right.$ and Qingfu Sun ${ }^{2, *}(\mathbb{C}$ \\ 1 College of Chemistry and Material Science, Fujian Normal University, Fuzhou 350007, China; \\ chengpm@fjirsm.ac.cn \\ 2 State Key Laboratory of Structural Chemistry, Fujian Institute of Research on the Structure of Matter \\ Chinese Academy of Sciences, Fuzhou 350002, China; lxcai@fjirsm.ac.cn (L.C.); yandanny@fjirsm.ac.cn (D.Y.); \\ zhoulp@fjirsm.ac.cn (L.Z.) \\ * Correspondence: qfsun@fjirsm.ac.cn
}

check for updates

Citation: Cheng, P.; Cai, L.; Yan, D.; Zhou, L.; Sun, Q. Molecular Cage Promoted Aerobic Oxidation or Photo-Induced Rearrangement of Spiroepoxy Naphthalenone. Catalysts 2021, 11, 484.

https://doi.org/10.3390/

catal11040484

Academic Editors: Simona M. Coman and Joanna Gościańska

Received: 20 March 2021

Accepted: 7 April 2021

Published: 9 April 2021

Publisher's Note: MDPI stays neutral with regard to jurisdictional claims in published maps and institutional affiliations.

Copyright: (c) 2021 by the authors. Licensee MDPI, Basel, Switzerland. This article is an open access article distributed under the terms and conditions of the Creative Commons Attribution (CC BY) license (https:// creativecommons.org/licenses/by/ $4.0 /)$.

\begin{abstract}
Herein, we report a $\mathrm{Pd}_{4} \mathrm{~L}_{2}$-type molecular cage (1) and catalyzed reactions of spiroepoxy naphthalenone (2) in water, where selective formation of 2-(hydroxymethyl)naphthalene-1,4-dione (3) via aerobic oxidation, or 1-hydroxy-2-naphthaldehyde (4) via photo-induced rearrangement under $\mathrm{N}_{2}$ have been accomplished. Encapsulation of four molecules of guest 2 within cage 1, i.e., (2) $\subset$ $\subset \mathbf{1}$, has been confirmed by NMR, and a final host-guest complex of $\mathbf{3} \subset \mathbf{1}$ has also been determined by single crystal X-Ray diffraction study. While the photo-induced ring-opening isomerization from 2 to 4 are known, appearance of charge-transfer absorption on the host-guest complex of $(2)_{4} \subset \mathbf{1}$ allows low-power blue LEDs irradiation to promote this process.
\end{abstract}

Keywords: supramolecular catalysis; host-guest chemistry; aerobic oxidation; rearrangement

\section{Introduction}

Artificial supramolecular architectures constructed via self-assembly with metal ions and organic ligands have attached tremendous attentions due to aesthetic structural diversity [1-12] and bio-mimic catalysis [13,14]. Among them, coordination molecular cages have been extensively studied as artificial enzyme-mimics to promote various reactions of the contained molecules within the confined space [15-19]. Cage catalyzed reactions can be classified into three pathways [20]: (1) cage promoted reactions directly; (2) modified cage to improve catalysis performance; (3) cooperation with other catalysts. For the cage promoted reactions, it is generally accepted that enhanced effective concentration and the pre-organization effect imposed to the guest molecules by the cage cavity contribute to the accelerated reaction rate and the improved product selectivity. To date, cage promoted cycloaddition [21,22], rearrangement [23,24], photocatalysis reactions [25-27], oxidation or reduction [28-32], nucleophilic addition [33,34], elimination [35] and acid or base-catalyzed addition [36-38] have been reported, and a part of works exhibit rate enhancement, amazing selectivity and wide substrate scope. Moreover, highly-charged molecular cages can perform catalysis in water, like enzymes do in nature. Recently, we have developed a redox-active coordination-assembled cage 1 (Scheme 1) based on bridged pyridinium ligands, which has been employed as a water-soluble bio-mimic catalyst [39]. The large hydrophobic cavity of cage $\mathbf{1}$ allows a variety of guests to be encapsulated, and the big apertures on the cage favor the product turn-over during catalysis [40].

Spiroepoxy-cyclohexdienones, one type of vinyl epoxides [41,42], are important building blocks for organic synthesis due to their highly reactive nature toward self-coupling Diels-Alder reactions [43]. We anticipate that new reaction pathways may be discovered if spiroepoxy-cyclohexdienones are entrapped within molecular cages. Herein, we report that cage 1 promoted aerobic oxidation and photo-induced isomerization reactions in water from spiroepoxy naphthalenone $\mathbf{2}$. In the presence of cage $\mathbf{1}$, both naphthoquinone 3 and 
aldehyde 4 can be selectively obtained by regulating the reaction conditions. It is worth to note that as a typical spiroepoxy-cyclohexdienones compound, reactivity of $\mathbf{2}$ has seldom been studied, with only one type of acid mediated rearrangement reaction being reported previously [44].

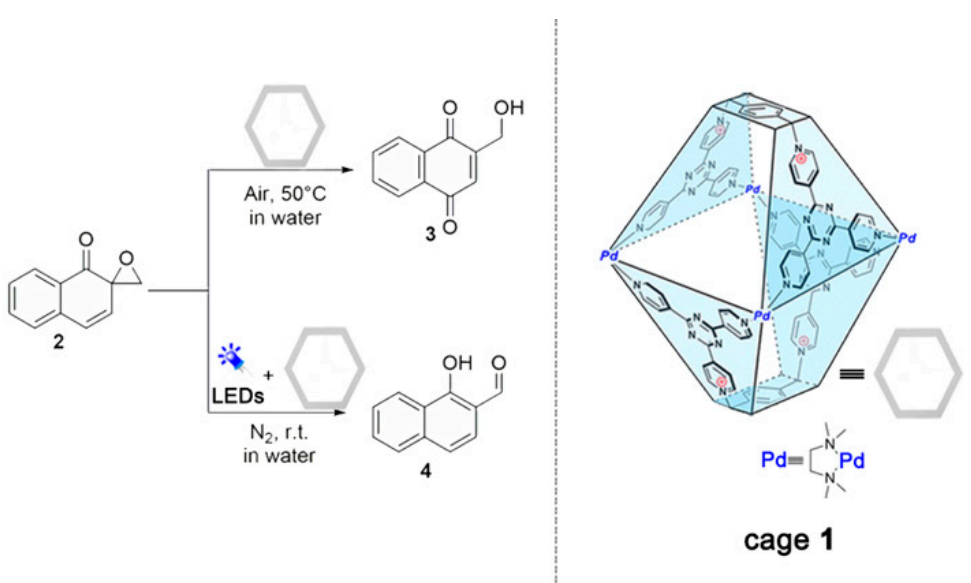

Scheme 1. Cage 1 promoted selective transformation from 2 to 3 or 4 .

\section{Results and Discussion}

Cage 1 and substrate 2 were synthesized according to the previous reports $[40,44]$. We started from the investigation of their host-guest chemistry. After excess amount of guest 2 was added to cage 1 in $\mathrm{D}_{2} \mathrm{O}$, the formation of a 1:4 host-guest complex was indicated by ${ }^{1} \mathrm{H}$ NMR spectra. Compared to the signals of free $\mathbf{2}$ (Figure 1a) and empty cage 1 (Figure 1b), the host-guest complex shows significant changes. Obvious up-field shifts for the aromatic signals on 2 from 8.1-5.9 ppm to 6.4-4.5 ppm, and the methylene signals from 3.4-3.1 ppm to 2.0-2.2 ppm were observed in ${ }^{1} \mathrm{H}$ NMR spectrum (Figure 1c), which indicates the efficient guest encapsulation within the hydrophobic cavity of cage $\mathbf{1}$. Moreover, integral ratio (Figure S3) confirms that four molecules of $\mathbf{2}$ could be encapsulated by 1 . Diffusion-ordered ${ }^{1} \mathrm{H}$ NMR spectroscopy $\left({ }^{1} \mathrm{H}\right.$ DOSY, Figure S4) also confirmed the formation of a single host-guest species with a diameter of $1.70 \mathrm{~nm}$ estimated from the Stokes-Einstein equation. The optimized host-guest complex model indicates that four molecules of $\mathbf{2}$ completely occupied the space of cavity within the cage $\mathbf{1}$ (Figure 2a).

Interestingly, after heating at $50{ }^{\circ} \mathrm{C}$ for $2 \mathrm{~h}$, the color of the solution for the initial (2) ${ }_{4} \subset 1$ complex changed gradually from yellow to deep red, and the dramatic change in ${ }^{1} \mathrm{H}$ NMR spectrum (Figure 1d) suggests the formation of a new host-guest complex. Characteristic signals for the encapsulated 2 (methylene signals) disappeared with the evolution of a new set of guest signals. After extraction by $\mathrm{CDCl}_{3}$, the final product was determined to be 2-(hydroxymethyl)naphthalene-1,4-dione (3) by NMR and GC-MS, with an NMR yield of over 99\% (Figure 1e and Figures S5-S7). A series of control experiments were carried out to confirm the indispensable role of cage 1 during this reaction. First of all, no such conversion was detected without cage 1 , under $\mathrm{N}_{2}$, or with ligand L only (entry $2-4)$. With the Pd salt (TMEDA)Pd( $\left.\mathrm{NO}_{3}\right)_{2}$ as catalyst, product 3 could only be obtained in a 39\% yield (entry 5). Considering previous reported work [39,45-50], we propose that redox-active nature of cage 1 plays a key role in this aerobic Wacker oxidation process.

To further confirm that efficient hydrophobic encapsulation is crucial for this conversion, a tetraphenylboron anion $\left(\mathrm{Ph}_{4} \mathrm{~B}^{-}\right.$, sodium salt) was chosen as a competition inhibitor which is known to strongly bind to cage $\mathbf{1}$ [40]. Although partial guest 2 can also enter the cavity of cage 1 in the presence of an inhibitor (Figure S8), a lower yield of 36\% was observed under the same conditions (entry 6, Figure S9). More importantly, when excess amount of guest 2 (100 equiv.) was added to the solution of cage $\mathbf{1}$ as a suspension, product 3 was formed in 95\% yield after heating for $4 \mathrm{~h}$, leading to a TON of 95 (entry 7). 


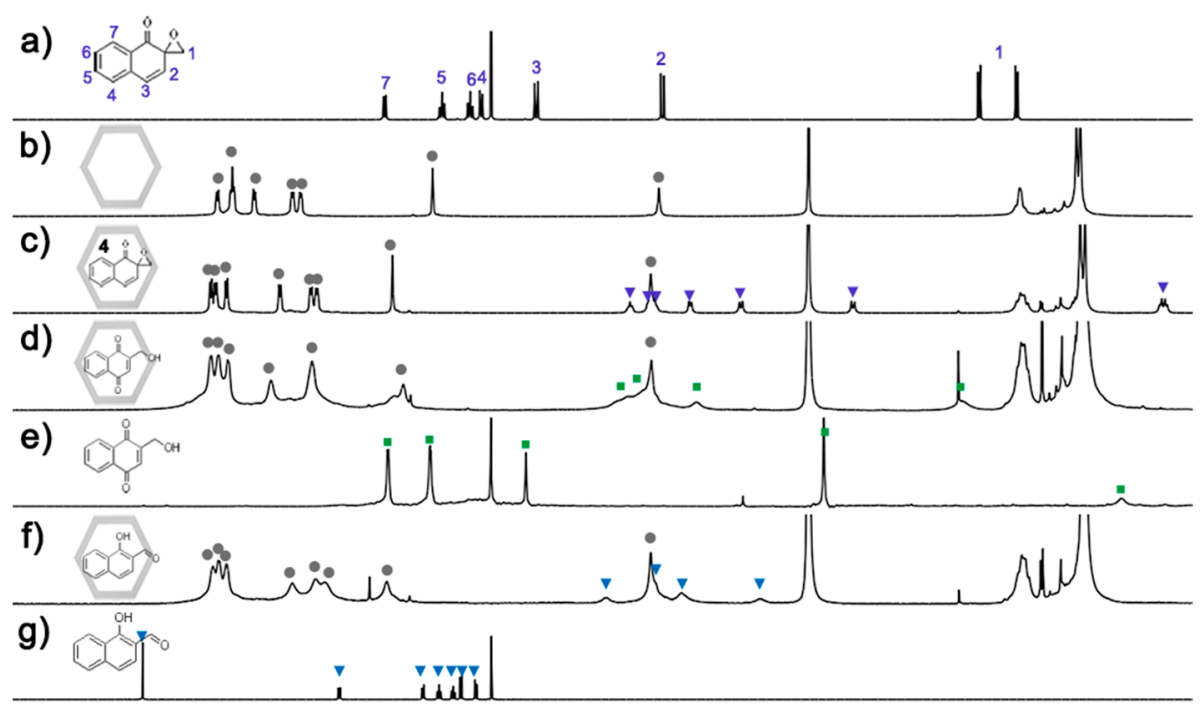

$\begin{array}{llllllllllllllllll}10.5 & 10.0 & 9.5 & 9.0 & 8.5 & 8.0 & 7.5 & 7.0 & 6.5 & 6.0 & 5.5 & 5.0 & 4.5 & 4.0 & 3.5 & 3.0 & 2.5 & \mathrm{ppm}\end{array}$

Figure 1. ${ }^{1} \mathrm{H}$ NMR (400 MHz, $\left.298 \mathrm{~K}\right)$ spectra of (a) 2 in $\mathrm{CDCl}_{3}$; (b) cage 1 in $\mathrm{D}_{2} \mathrm{O}$; (c) host-guest complex of (2) $)_{4} \subset \mathbf{1}$ in $\mathrm{D}_{2} \mathrm{O}$ and (d) (2) $)_{4} \subset \mathbf{1}$ in $\mathrm{D}_{2} \mathrm{O}$ after heating at $50{ }^{\circ} \mathrm{C}$ for $2 \mathrm{~h}$; (e) extracted 3 in $\mathrm{CDCl}_{3} ;(\mathbf{f})(2)_{4} \subset \mathbf{1}$ in $\mathrm{D}_{2} \mathrm{O}$ after blue LEDs irradiation under $\mathrm{N}_{2}$ atmosphere at r.t. for $8 \mathrm{~h} ;(\mathrm{g})$ extracted 4 in $\mathrm{CDCl}_{3} ;(\nabla: 2, \square: 3, \bullet$ : cage $1, \nabla: 4)$.

a)

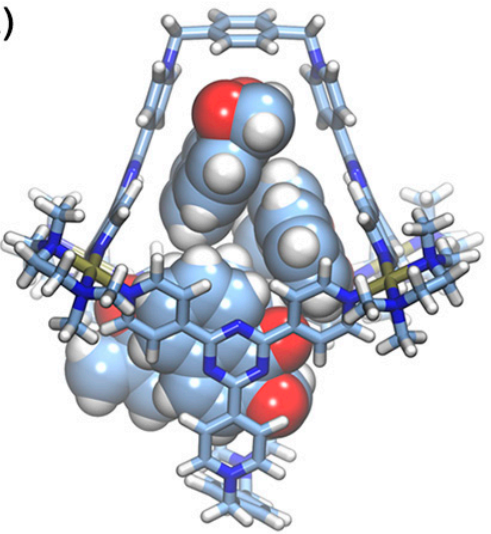

b)

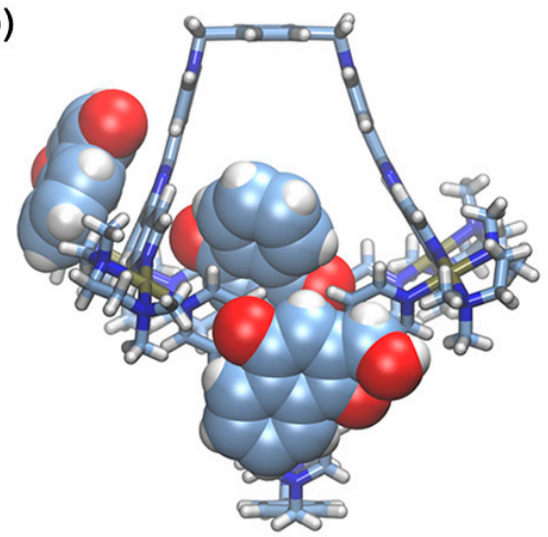

Figure 2. (a) Optimized structure of (2) ${ }_{4} \subset \mathbf{1}$ based on molecular mechanical simulation; (b) X-ray structure of $\mathbf{3} \subset \mathbf{1}$ host-guest complex. (cage $\mathbf{1}$ and guests $\mathbf{2}$ or $\mathbf{3}$ are displayed with stick and sphere models, respectively. C: wathet blue, N: blue, O: red, Pd: brown. Counterions are omitted for clarity).

DFT calculation indicated that the $\mathrm{C} 2-\mathrm{O} 2$ bond between the naphthalene ring and the epoxy group was longer than the $\mathrm{O} 2-\mathrm{C} 5$ bond, suggesting that the epoxy group tended to undergo ring-opening reaction (Figure 3a). In fact, a previous report [51] revealed that substrate 2 can undergo a photo-induced ring-opening rearrangement to form 1-hydroxy2-naphthaldehyde 4 by purple LEDs irradiation. UV-vis spectra (Figure $3 b$ ) measurements suggest that a new shoulder peak tailing up to visible region appeared for the (2) ${ }_{4} \subset \mathbf{1}$ host-guest complex, assignable to host-guest charge transform (CT) absorption. Indeed, under blue LEDs irradiation, cage $\mathbf{1}$ promoted isomerization reaction of $\mathbf{2}$ to $\mathbf{4}$ has been observed in $90 \%$ yield after $8 \mathrm{~h}$, which is a significant improvement comparing to that in the absence of cage 1 under the same conditions (Table 1, entry 8 and 9). Considering that conversion from $\mathbf{2}$ to 3 is a competition pathway under air in the presence of cage $\mathbf{1}$, this photo-induced isomerization has to be carried out under $\mathrm{N}_{2}$ atmosphere. In this case, cage 1 not only plays as a phase transfer catalyst but also facilitates the visible light absorption by the formation of host-guest CT complex. 
a)

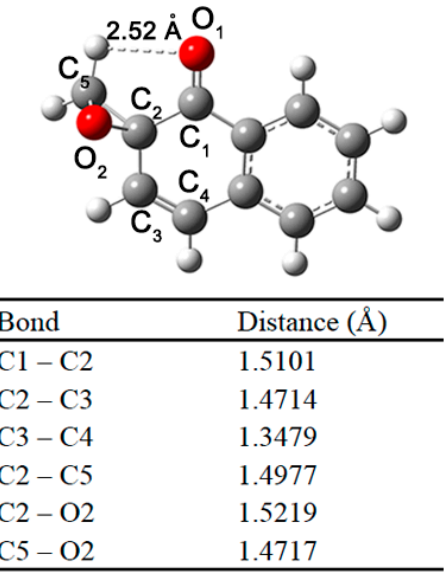

b)

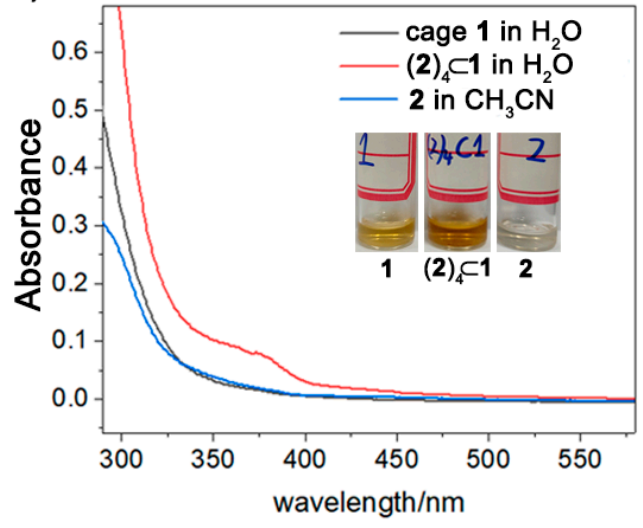

Figure 3. (a) DFT calculated structure of 2 with selected bond lengths; (b) UV-vis absorption spectra for cage $\mathbf{1}$, guest 2 and the $(2)_{4} \subset \mathbf{1}$ host-guest complex $\left(1 \times 10^{-5} \mathrm{M}\right)$, with their pictures shown.

Table 1. Cage $\mathbf{1}$ promoted reaction of guest 2 under different conditions*.<smiles>O=C1c2ccccc2C=CC12CO2</smiles>

2<smiles>O=Cc1ccc2ccccc2c1O</smiles>

3 4

\begin{tabular}{|c|c|c|c|c|c|c|c|c|}
\hline \multirow{3}{*}{$\begin{array}{c}\text { Entry } \\
1\end{array}$} & \multirow{3}{*}{$\begin{array}{c}\text { Catalyst } \\
1\end{array}$} & \multirow{2}{*}{\multicolumn{2}{|c|}{ Conditions }} & \multirow{3}{*}{$\begin{array}{c}\text { LEDs } \\
-\end{array}$} & \multirow{3}{*}{$\begin{array}{c}\text { Time } \\
\text { (h) }\end{array}$} & \multirow{3}{*}{$\begin{array}{c}\text { Solvent } \\
\mathrm{D}_{2} \mathrm{O}\end{array}$} & \multicolumn{2}{|c|}{ Yield $^{a}$} \\
\hline & & & & & & & \multirow{2}{*}{$\begin{array}{c}3 \\
>99 \%\end{array}$} & \multirow{2}{*}{$\begin{array}{l}4 \\
-\end{array}$} \\
\hline & & Air & $50{ }^{\circ} \mathrm{C}$ & & & & & \\
\hline 2 & - & Air & $50^{\circ} \mathrm{C}$ & - & $2 \mathrm{~h}$ & $\mathrm{H}_{2} \mathrm{O}$ & - & - \\
\hline 3 & 1 & $\mathrm{~N}_{2}$ & $50^{\circ} \mathrm{C}$ & - & $2 \mathrm{~h}$ & $\mathrm{D}_{2} \mathrm{O}$ & - & - \\
\hline $4^{b}$ & $\mathrm{~L}$ & Air & $50{ }^{\circ} \mathrm{C}$ & - & $2 \mathrm{~h}$ & $\mathrm{H}_{2} \mathrm{O}$ & - & - \\
\hline $5^{c}$ & $\mathrm{Pd}$ & Air & $50^{\circ} \mathrm{C}$ & - & $2 \mathrm{~h}$ & $\mathrm{H}_{2} \mathrm{O}$ & $39 \%$ & - \\
\hline 6 & $\mathrm{Ph}_{4} \mathrm{~B} \subset 1$ & Air & $50{ }^{\circ} \mathrm{C}$ & - & $2 \mathrm{~h}$ & $\mathrm{D}_{2} \mathrm{O}$ & $36 \%$ & - \\
\hline $7^{d}$ & 1 & Air & $50{ }^{\circ} \mathrm{C}$ & - & $4 \mathrm{~h}$ & $\mathrm{D}_{2} \mathrm{O}$ & $95 \%$ & - \\
\hline 8 & 1 & $\mathrm{~N}_{2}$ & r.t. & blue & $8 \mathrm{~h}$ & $\mathrm{D}_{2} \mathrm{O}$ & - & $90 \%$ \\
\hline 9 & - & Air & r.t. & blue & $8 \mathrm{~h}$ & $\mathrm{H}_{2} \mathrm{O}$ & - & $32 \%$ \\
\hline
\end{tabular}

* Unless otherwise stated, all experiments were carried out with $0.01 \mathrm{mmol}$ of $\mathbf{2}$ and $25 \%$ mol of cage $\mathbf{1}$ in water The power of LEDs is ca. $6 \mathrm{~W}$. ${ }^{a}$ : Yields were determined from ${ }^{1} \mathrm{H}$ NMR spectra using 1,3,5-trimethoxybenzene as the inner standard. ${ }^{b}: 10 \% \mathrm{~mol}$ of ligand was used as catalyst. ${ }^{c}: 10 \%$ mol of Pd salt $\left[(\mathrm{TMEDA}) \mathrm{Pd}\left(\mathrm{NO}_{3}\right)_{2}\right]$ was used as catalyst. $^{d}$ : $1 \%$ mol of cage 1 was used and reaction was carried under suspension condition.

To our delight, dark red crystals were obtained by slow evaporation of the final reaction solution at room temperature over one week. The crystals were of sufficient quality and X-ray crystallography finally established the structure of the new host-guest complex, which contained product 3 and cage $\mathbf{1}$ (Appendix A). X-ray structure revealed that there was only one molecule of 3 sitting inside in the inner cavity of the cage, along with two molecules of 3 binding to the external panels of the cage (Figure $2 b$ ). The external binding of the products explains product replacement of start material observed during the above catalysis.

\section{Conclusions}

To conclude, we have revealed a condition-controlled supramolecular cage catalyzed reaction for a spiroepoxy-naphthalenone guest molecule, where both quinone product 3 and aldehyde product 4 can be obtained selectively in good yields. Such coordination-cagepromoted selective transformations from one starting material toward different products is still rare in supramolecular catalysis. This approach promised a potential application for cage catalyzed oxidation and photo-isomerization reactions. Further development of catalytic reactions by using cage $\mathbf{1}$ as an artificial enzyme-mimic is still underway. 


\section{Materials and Methods}

\subsection{General}

Unless otherwise stated, all chemicals and solvents were purchased from commercial companies (AdamasReagent Ltd., Shanghai, China; J\&K Scientific Ltd., Beijing, China, and Sigma-Aldrich LLC., Darmstadt, Germany. etc) and used without further purification. 1D and 2D-NMR were measured on a Bruker Biospin Avance III (400 MHz) spectrometer or JEOL JNM-ECZ600R/S1 (600 MHz) spectrometer. ${ }^{1} \mathrm{H}-\mathrm{NMR}$ chemical shifts were determined with tetramethylsilane (TMS) or respect to residual signals of the deuterated solvents used ( $\delta=4.79$ for $\mathrm{D}_{2} \mathrm{O}$ in ${ }^{1} \mathrm{H}$ NMR). The photoreactors used in this research were bought from Wuhan Geao Instruments Science and Technology Co., Ltd. (Wuhan, China) (Purple LEDs, light intensity $=37.4 \mathrm{mw} / \mathrm{cm}^{2}, \lambda_{\max }=390 \mathrm{~nm}$; Blue LEDs, $\lambda_{\max }=450 \mathrm{~nm}$; $1 \mathrm{~W}$ for every light bulb; every Schlenk tube was irradiated by 6 light bulbs from the side). Gas chromatography mass spectrometry (GC-MS) analyses were performed on a Shimadzu GCMS-QP2010SE instrument. ESI-TOF-MS were recorded on Impact II UHR-TOF from Bruker. Data analysis was conducted with the Bruker Data Analysis software (Version 4.3, Bruker Daltonik GmbH, Bremen, Germany) and simulations were performed with the Bruker Isotope Pattern software. UV-vis adsorption spectra were recorded on UV-2700 UV-visible spectrophotometer from SHIMADZU Corporation.

\subsection{Preparation and Catalysis Procedure}

The general catalysis procedure and all the characterization data of the products as well as the procedures to prepare are listed in the Supplementary Materials online. The known compounds were recorded in the previous report.

\subsection{Computational Methods}

Molecular modeling of host-guest complex (2) $)_{4} \subset \mathbf{1}$ was optimized by force-field calculation carried on Material Studio software by Quasi-Newton Methods which was based on a previously reported cage $\mathbf{1} X$-ray structure [39]. Structure optimization of guest $\mathbf{2}$ which was carried at B3LYP/6-31G level by gaussian software [52].

Supplementary Materials: The following are available online at https://www.mdpi.com/article/ 10.3390/catal11040484/s1. Figures S1-S21: synthesis procedure, catalysis procedure, NMR spectra, ESI-TOF-MS, GC-MS and Single-Crystal information.

Author Contributions: Conceptualization, Q.S. and P.C.; writing—original draft preparation, P.C.; writing - review and editing, Q.S.; P.C. performed most of the experiments and analyzed the data, L.C., D.Y., L.Z. helped with synthesis/characterization and joined the discussion. All authors have read and agreed to the published version of the manuscript.

Funding: This research was funded by the National Natural Science Foundation of China (Grant Nos. 21825107, 21801241), the Strategic Priority Research Program of the Chinese Academy of Sciences (Grant No. XDB20000000).

Data Availability Statement: All data generated or analyzed during this study are included in this article.

Conflicts of Interest: The authors declare no conflict of interest.

\section{Appendix A}

Crystallographic data for the structures of host-guest complex of product 3 and cage 1 have been deposited to the Cambridge Crystallographic Data Centre as supplementary No.: CCDC-2065411. 


\section{References}

1. Fujita, D.; Ueda, Y.; Sato, S.; Yokoyama, H.; Mizuno, N.; Kumasaka, T.; Fujita, M. Self-Assembly of M 30 L 60 Icosidodecahedron. Chem 2016, 1, 91-101. [CrossRef]

2. Yang, D.; Greenfield, J.L.; Ronson, T.K.; Von Krbek, L.K.S.; Yu, L.; Nitschke, J.R. LaIII and ZnII Cooperatively Template a Metal-Organic Capsule. J. Am. Chem. Soc. 2020, 142, 19856-19861. [CrossRef]

3. Cheng, P.; Cai, L.; Li, S.; Hu, S.; Yan, D.; Zhou, L.; Sun, Q. Guest-Reaction Driven Cage to Conjoined Twin-Cage Mitosis-Like Host Transformation. Angew. Chem. Int. Ed. 2020, 59, 23569-23573. [CrossRef]

4. Zhang, Z.; Li, Y.; Song, B.; Zhang, Y.; Jiang, X.; Wang, M.; Trumbleson, R.; Liu, C.; Wang, P.; Hao, X.-Q.; et al. Intra- and intermolecular self-assembly of a 20-nm-wide supramolecular hexagonal grid. Nat. Chem. 2020, 12, 468-474. [CrossRef]

5. Cai, L.-X.; Yan, D.-N.; Cheng, P.-M.; Xuan, J.-J.; Li, S.-C.; Zhou, L.-P.; Tian, C.-B.; Sun, Q.-F. Controlled Self-Assembly and Multistimuli-Responsive Interconversions of Three Conjoined Twin-Cages. J. Am. Chem. Soc. 2021, 143, 2016-2024. [CrossRef]

6. Liu, D.; Li, K.; Chen, M.; Zhang, T.; Li, Z.; Yin, J.-F.; He, L.; Wang, J.; Yin, P.; Chan, Y.-T.; et al. Russian-Doll-Like Molecular Cubes. J. Am. Chem. Soc. 2021, 143, 2537-2544. [CrossRef] [PubMed]

7. Fang, Y.; Xiao, Z.; Li, J.; Lollar, C.; Liu, L.; Lian, X.; Yuan, S.; Banerjee, S.; Zhang, P.; Zhou, H.-C. Formation of a Highly Reactive Cobalt Nanocluster Crystal within a Highly Negatively Charged Porous Coordination Cage. Angew. Chem. Int. Ed. 2018, 57, 5283-5287. [CrossRef]

8. Zhang, X.; Dong, X.; Lu, W.; Luo, D.; Zhu, X.-W.; Li, X.; Zhou, X.-P.; Li, D. Fine-Tuning Apertures of Metal-Organic Cages: Encapsulation of Carbon Dioxide in Solution and Solid State. J. Am. Chem. Soc. 2019, 141, 11621-11627. [CrossRef]

9. Wu, G.-Y.; Shi, X.; Phan, H.; Qu, H.; Hu, Y.-X.; Yin, G.-Q.; Zhao, X.-L.; Li, X.; Xu, L.; Yu, Q.; et al. Efficient self-assembly of heterometallic triangular necklace with strong antibacterial activity. Nat. Commun. 2020, 11, 1-11. [CrossRef] [PubMed]

10. Gao, W.-X.; Feng, H.-J.; Guo, B.-B.; Lu, Y.; Jin, G.-X. Coordination-Directed Construction of Molecular Links. Chem. Rev. 2020, 120, 6288-6325. [CrossRef] [PubMed]

11. Lu, Y.; Liu, D.; Lin, Y.-J.; Li, Z.-H.; Jin, G.-X. Self-assembly of metalla[3]catenanes, borromean rings and ring-in-ring complex using a simple $\pi$-donor unit. Natl. Sci. Rev. 2020, 7, 1548-1556. [CrossRef]

12. Huang, S.-L.; Lin, Y.-J.; Li, Z.-H.; Jin, G.-X. Self-Assembly of Molecular Borromean Rings from Bimetallic Coordination Rectangles. Angew. Chem. Int. Ed. 2014, 53, 11218-11222. [CrossRef] [PubMed]

13. Brown, C.J.; Toste, F.D.; Bergman, R.G.; Raymond, K.N. Supramolecular Catalysis in Metal-Ligand Cluster Hosts. Chem. Rev. 2015, 115, 3012-3035. [CrossRef]

14. Yoshizawa, M.; Klosterman, J.K.; Fujita, M. Functional Molecular Flasks: New Properties and Reactions within Discrete, SelfAssembled Hosts. Angew. Chem. Int. Ed. 2009, 48, 3418-3438. [CrossRef] [PubMed]

15. Tan, C.; Chu, D.; Tang, X.; Liu, Y.; Xuan, W.; Cui, Y. Supramolecular Coordination Cages for Asymmetric Catalysis. Chem. A Eur. J. 2019, 25, 662-672. [CrossRef] [PubMed]

16. Pan, M.; Wu, K.; Zhang, J.-H.; Su, C.-Y. Chiral metal-organic cages/containers (MOCs): From structural and stereochemical design to applications. Coord. Chem. Rev. 2019, 378, 333-349. [CrossRef]

17. Zhao, L.; Jing, X.; Li, X.; Guo, X.; Zeng, L.; He, C.; Duan, C. Catalytic properties of chemical transformation within the confined pockets of Werner-type capsules. Coord. Chem. Rev. 2019, 378, 151-187. [CrossRef]

18. Morimoto, M.; Bierschenk, S.M.; Xia, K.T.; Bergman, R.G.; Raymond, K.N.; Toste, F.D. Advances in supramolecular host-mediated reactivity. Nat. Catal. 2020, 3, 969-984. [CrossRef]

19. Percástegui, E.G.; Ronson, T.K.; Nitschke, J.R. Design and Applications of Water-Soluble Coordination Cages. Chem. Rev. 2020, 120, 13480-13544. [CrossRef]

20. Fang, Y.; Powell, J.A.; Li, E.; Wang, Q.; Perry, Z.; Kirchon, A.; Yang, X.; Xiao, Z.; Zhu, C.; Zhang, L.; et al. Catalytic reactions within the cavity of coordination cages. Chem. Soc. Rev. 2019, 48, 4707-4730. [CrossRef]

21. Merget, S.; Catti, L.; Piccini, G.; Tiefenbacher, K. Requirements for Terpene Cyclizations inside the Supramolecular Resorcinarene Capsule: Bound Water and Its Protonation Determine the Catalytic Activity. J. Am. Chem. Soc. 2020, 142, 4400-4410. [CrossRef] [PubMed]

22. Hastings, C.J.; Pluth, M.D.; Bergman, R.G.; Raymond, K.N. Enzymelike Catalysis of the Nazarov Cyclization by Supramolecular Encapsulation. J. Am. Chem. Soc. 2010, 132, 6938-6940. [CrossRef] [PubMed]

23. Hastings, C.J.; Fiedler, D.; Bergman, R.G.; Raymond, K.N. Aza Cope Rearrangement of Propargyl Enammonium Cations Catalyzed by a Self-Assembled "Nanozyme". J. Am. Chem. Soc. 2008, 130, 10977-10983. [CrossRef]

24. Hong, C.M.; Morimoto, M.; Kapustin, E.A.; Alzakhem, N.; Bergman, R.G.; Raymond, K.N.; Toste, F.D. Deconvoluting the Role of Charge in a Supramolecular Catalyst. J. Am. Chem. Soc. 2018, 140, 6591-6595. [CrossRef] [PubMed]

25. Zhao, L.; Cai, J.; Li, Y.; Wei, J.; Duan, C. A host-guest approach to combining enzymatic and artificial catalysis for catalyzing biomimetic monooxygenation. Nat. Commun. 2020, 11, 1-11. [CrossRef]

26. Guo, J.; Fan, Y.; Lu, Y.; Zheng, S.; Su, C. Visible-Light Photocatalysis of Asymmetric [2+2] Cycloaddition in Cage-Confined Nanospace Merging Chirality with Triplet-State Photosensitization. Angew. Chem. Int. Ed. 2020, 59, 8661-8669. [CrossRef]

27. Wang, J.-S.; Wu, K.; Yin, C.; Li, K.; Huang, Y.; Ruan, J.; Feng, X.; Hu, P.; Su, C.-Y. Cage-confined photocatalysis for wide-scope unusually selective [2 + 2] cycloaddition through visible-light triplet sensitization. Nat. Commun. 2020, 11, 1-9. [CrossRef]

28. Zaffaroni, R.; Orth, N.; Ivanović-Burmazović, I.; Reek, J.N.H. Hydrogenase Mimics in M 12 L 24 Nanospheres to Control Overpotential and Activity in Proton-Reduction Catalysis. Angew. Chem. Int. Ed. 2020, 59, 18485-18489. [CrossRef] 
29. Lai, Y.-L.; Wang, X.-Z.; Dai, R.-R.; Huang, Y.-L.; Zhou, X.-C.; Zhou, X.-P.; Li, D. Self-assembly of mixed-valence and heterometallic metallocycles: Efficient catalysts for the oxidation of alcohols to aldehydes in ambient air. Dalton Trans. 2020, 49, 7304-7308. [CrossRef] [PubMed]

30. Ding, C.-W.; Luo, W.; Zhou, J.-Y.; Ma, X.-J.; Chen, G.-H.; Zhou, X.-P.; Li, D. Hydroxo Iron(III) Sites in a Metal-Organic Framework: Proton-Coupled Electron Transfer and Catalytic Oxidation of Alcohol with Molecular Oxygen. ACS Appl. Mater. Interfaces 2019, 11, 45621-45628. [CrossRef] [PubMed]

31. Fang, Y.; Li, J.; Togo, T.; Jin, F.; Xiao, Z.; Liu, L.; Drake, H.; Lian, X.; Zhou, H.-C. Ultra-Small Face-Centered-Cubic Ru Nanoparticles Confined within a Porous Coordination Cage for Dehydrogenation. Chem 2018, 4, 555-563. [CrossRef]

32. Jiang, W.-L.; Shen, J.-C.; Peng, Z.; Wu, G.-Y.; Yin, G.-Q.; Shi, X.; Yang, H.-B. Controllable synthesis of ultrasmall Pd nanocatalysts templated by supramolecular coordination cages for highly efficient reductive dehalogenation. J. Mater. Chem. A 2020, 8, 12097-12105. [CrossRef]

33. Wang, J.; Young, T.A.; Duarte, F.; Lusby, P.J. Synergistic Noncovalent Catalysis Facilitates Base-Free Michael Addition. J. Am. Chem. Soc. 2020, 142, 17743-17750. [CrossRef]

34. Zhu, F.-F.; Chen, L.-J.; Chen, S.; Wu, G.-Y.; Jiang, W.-L.; Shen, J.-C.; Qin, Y.; Xu, L.; Yang, H.-B. Confinement Self-Assembly of Metal-Organic Cages within Mesoporous Carbon for One-Pot Sequential Reactions. Chem 2020, 6, 2395-2406. [CrossRef]

35. Cullen, W.; Misuraca, M.C.; Hunter, M.C.M.C.A.; Williams, N.H.; Ward, W.C.N.H.W.M.D. Highly efficient catalysis of the Kemp elimination in the cavity of a cubic coordination cage. Nat. Chem. 2016, 8, 231-236. [CrossRef] [PubMed]

36. Ngai, C.; Sanchez-Marsetti, C.M.; Harman, W.H.; Hooley, R.J. Supramolecular Catalysis of the oxa-Pictet-Spengler Reaction with an Endohedrally Functionalized Self-Assembled Cage Complex. Angew. Chem. Int. Ed. 2020, 59, 23505-23509. [CrossRef] [PubMed]

37. Takezawa, H.; Shitozawa, K.; Fujita, M. Enhanced reactivity of twisted amides inside a molecular cage. Nat. Chem. 2020, 12, 574-578. [CrossRef] [PubMed]

38. Yang, J.; Châtelet, B.; Dufaud, V.; Hérault, D.; Michaud-Chevallier, S.; Robert, V.; Dutasta, J.-P.; Martinez, A. Endohedral Functionalized Cage as a Tool to Create Frustrated Lewis Pairs. Angew. Chem. Int. Ed. 2018, 57, 14212-14215. [CrossRef]

39. Cai, L.-X.; Li, S.-C.; Yan, D.-N.; Zhou, L.-P.; Guo, F.; Sun, Q.-F. Water-Soluble Redox-Active Cage Hosting Polyoxometalates for Selective Desulfurization Catalysis. J. Am. Chem. Soc. 2018, 140, 4869-4876. [CrossRef]

40. Li, S.-C.; Cai, L.-X.; Zhou, L.-P.; Guo, F.; Sun, Q.-F. Supramolecular synthesis of coumarin derivatives catalyzed by a coordinationassembled cage in aqueous solution. Sci. China Ser. B Chem. 2019, 62, 713-718. [CrossRef]

41. Gesson, J.-P.; Mondon, M.; Pokrovska, N. Synthesis of Fused Aromatic [1,3]Dioxoles from 2-Hydroxymethylphenols. Synlett 1997, 12, 1395-1396. [CrossRef]

42. He, J.; Ling, J.; Chiu, P. Vinyl Epoxides in Organic Synthesis. Chem. Rev. 2014, 114, 8037-8128. [CrossRef]

43. Xin, M.; Bugg, T.D.H. Biomimetic Formation of 2-Tropolones by Dioxygenase-Catalysed Ring Expansion of Substituted 2,4Cyclohexadienones. ChemBioChem 2009, 11, 272-276. [CrossRef]

44. Tius, M.A.; Reddy, N.K. Stereoselective Synthesis of Disubstituted Naphthalene-1,2-oxides. Synth. Commun. 1994, 24, 859-869. [CrossRef]

45. Yoshizawa, M.; Sato, N.; Fujita, M. Selective Enclathration of Linear Alkanols by a Self-assembled Coordination Cage. Application to the Catalytic Wacker Oxidation of $\omega$-Alkenols. Chem. Lett. 2005, 34, 1392-1393. [CrossRef]

46. Mahmudov, K.T.; Gurbanov, A.V.; Guseinov, F.I.; da Silva, M.F.C.G. Noncovalent interactions in metal complex catalysis. Coord. Chem. Rev. 2019, 387, 32-46. [CrossRef]

47. Ma, Z.; Mahmudov, K.T.; Aliyeva, V.A.; Gurbanov, A.V.; Pombeiro, A.J. TEMPO in metal complex catalysis. Coord. Chem. Rev. 2020, 423, 213482. [CrossRef]

48. Ma, Z.; Mahmudov, K.T.; Aliyeva, V.A.; Gurbanov, A.V.; da Silva, M.F.C.G.; Pombeiro, A.J. Peroxides in metal complex catalysis. Coord. Chem. Rev. 2021, 437, 213859. [CrossRef]

49. Higuchi, M.; Yamaguchi, S.; Hirao, T. Construction of Palladium-Polypyrrole Catalytic System in the Wacker Oxidation. Synlett 1996, 1996, 1213-1214. [CrossRef]

50. Mitsudome, T.; Umetani, T.; Nosaka, N.; Mori, K.; Mizugaki, T.; Ebitani, K.; Kaneda, K. Convenient and Efficient Pd-Catalyzed Regioselective Oxyfunctionalization of Terminal Olefins by Using Molecular Oxygen as Sole Reoxidant. Angew. Chem. Int. Ed. 2006, 45, 481-485. [CrossRef] [PubMed]

51. Becker, H.-D.; Bremholt, T.; Adler, E. Oxidative formation and photochemical isomerization of spiro-epoxy-2,4-cyclohexadienones. Tetrahedron Lett. 1972, 13, 4205-4208. [CrossRef]

52. Frisch, M.J.; Trucks, G.W.; Schlegel, H.B.; Scuseria, G.E.; Robb, M.A.; Cheeseman, J.R.; Scalmani, G.; Barone, V.; Mennucci, B.; Petersson, G.A.; et al. Gaussian 09, Revision E.01; Gaussian, Inc.: Wallingford, CT, USA, 2013. 